\title{
Detecting Cronobacter Contamination in Protein Mixture and Biscuit Sample by Conventional PCR Method-A Preliminary Study
}

\author{
Mehal Passi, Nakul Aggarwal and Anu Priya Minhas*
}

Department of Biotechnology, UIET, Panjab University, Chandigarh, India

*Corresponding author

\section{Keywords}

Cronobacter, PCR, Enterobacteriaceae, rpoB , ITS.

\section{Article Info}

Accepted:

04 October 2016

Available Online:

10 November 2016

\section{A B S T R A C T}

Cronobacter is a gram negative, non-sporulating rod shaped bacteria. It is a known contaminant of different dried milk products, mainly powdered infant formula. Cronobacter is responsible for meningitis and enteritis especially in neonates. However elderly people and children with compromised immunity are also at risk. To detect Cronobacter contamination in food samples, various microbiological, immunological and molecular methods with variable specificity and sensitivity has been developed. This study focus on molecular detection of Cronobacter in some food products employing rpoB and ITS based PCR strategy. Total of six samples were screened with microbiological methods and positive samples were further confirmed using rpoB and ITS based conventional PCR. Although 50\% tested sample were found contaminated with such bacteria, still it is a very preliminary study in such food samples requiring further investigation. ITS and rpoB sequence chosen from previous studies were conserved sequences among Cronobacter strains. Therefore probability of primer (based on these sequence) to bind at specific locus in different strains will be more. However only rpoB based primer pair successfully amplified rpoB specific sequence in three out of six food samples tested. No such amplification was observed when ITS based primer pair was used in PCR. In spite of all, such food contaminations are a matter of concern, reflecting poor handling, processing, preparation and storage procedures therefore challenging health of children and immune-compromised patients.

\section{Introduction}

Genus Cronobacter contains gram negative, rod shaped and non-sporulating bacteria and belongs to the family Enterobacteriaceae (Farmer et al., 1980; Iverson et al., 2007a, 2008). Till date only seven species has been identified under the genus Cronobacter. Cronobacter is reclassified form of genus Enterobacter cloacae, which under the genus Cronobacter.
Biochemically Chronobacter spp. has been characterized to have catalase and unique $\alpha$ D-glucosidase activity with no oxidase activity (Muytjens et al., 1988). It is a foodborne and opportunistic pathogens causing life-threatening infections affecting neonates specially low birth weight badies. However elderly persons and/or children with compromised immunity are also target of 
such infection. (Bar-Oz et al., 2001; Gurtler et al., 2005; Anonymous, 2006 a,b; Mullane et al., 2007a). Its ability to form capsular film helps in its adherence to intestinal and macrophages cell surface where in macrophages they can survive for long period of time. All these factors contribute towards its virulence (Iversen and Forsythe, 2004). Clinical syndromes of Cronobacter infection include necrotizing enterocolitis (NEC), bacteraemia and meningitis, with fatality rates between $40 \%$ and $80 \%$ (Bowen and Braden, 2006; Friedemann, 2009). Cronobacter spp. has been detected and isolated from a wide variety of environmental and food samples including dairy-based foods, dried meats, water, rice and infant formula (Baumgartner et al., 2009; Chap et al., 2009; Healy et al., 2010). For isolation of this bacterium the recommended media by the International Organization for StandardizationInternational Dairy Federation include DFI medium, OK medium, Enterobacter sakazakii chromogenic plating medium (ESPM), Enterobacter sakazakii isolation agar (ESIA),Violet Red Bile Glucose Agar (VRBGA) (Besse et al., 2006; Iversen et al., 2004; Oh and Kang, 2004; Restaino, et al., 2006). C. sakazakii when grown on nutrient agar at $37^{\circ} \mathrm{C}$ produces slightly yellowpigment but at room temperature it forms non-diffusible yellow-gold pigment (Arshan. et al., 2013). Cronobacter spp. has been isolated specifically from powdered infant formulae as this bacterium has characteristic high tolerance to desiccation which helps this bacterium to survive in dry environment of milk factories (Mullane et al., 2006). Different detection strategies include conventional media based, immnunological and molecular based method. Among molecular methods Polymerase Chain Reaction (PCR), real-time PCR, DNA microarray-based assays based on unique genes or regions of this pathogen have been employed for Cronobacter diagnostics (Bej et al., 2003; Wang et al., 2009). Some of these unique sequences are 16S rRNA, intergenic region between $16 \mathrm{~S}$ rRNA-23S rDNA, dnaG, ompA, 1,6 $\alpha$-glucosidase and RNA polymerase encoding genes Iversen et al., (2004a, 2007a, 2007b), Derzelle et al., (2007), Hassan et al., (2007); Almeida et al., (2009); Seo and Brackett (2005); Drudy et al., (2006); Jaradat et al., (2009); Nair and Venkitanarayanan (2006); Mullane et al., (2008a); Jarvis et al., 2011); Stoop et al., (2009).

rpoB and ITS are the conserved regions among Cronobacter genus with little difference in length and primary sequence. The $r p o B$ gene ( 1342 amino acids) encodes $\beta$ subunit of bacterial RNA polymerase, the second largest polypeptide present in bacterial cell. Internal transcribed spacer (ITS) sequence is the sequence between tRNA-glu and 23S rRNA genes. Real time PCR based on these sequence has been reported to detect multiple species of Cronobacter genus with a mismatch-PCRbased approach (Stoop et al., 2009) (Sylviane Derzelle and Françoise Dilasser, 2006). Simple conventional PCR was performed with microbiologically positive samples. A total of six samples were tested on selective media. For PCR detection, two sets of primers based on above mentioned sequences were employed. Presence or absence of amplified product was analyzed on $0.8 \%$ agarose gel for confirming Cronobacter contamination. Samples used in this study were health drinks and high calories protein biscuits.

\section{Materials and Methods}

\section{Food sample collection}

Six food samples tested were procured from confectionary stores located in vicinity of 
Chandigarh, India. Three health drinks sample were A, B, C while three high calories protein biscuits were D, E, F. It was carefully noted that none of samples is expired or seal tampered. All the samples were certified by Food Safety and Standard Authority of India (FSSAI).

\section{Media and Reagents}

Tryptone Soy Agar (TSA) (HiMedia) and Violet Red Bile Glucose (VRBG) (HiMedia) agar were used as nutrient and selective media respectively for isolating Enterobacteriaceae in this study. TSA contain Pancreatic digest of casein $17 \mathrm{~g} / 1$, papaic digest of soyabean meal $3 \mathrm{~g} / \mathrm{l}$, sodium chloride $5 \mathrm{~g} / 1$, dextrose $2.5 \mathrm{~g} / 1$, dibasic potassium phosphate $2.5 \mathrm{~g} / 1, \mathrm{pH} 7.3 \pm 0.2$. Composition of VRBG include yeast extract $3 \mathrm{~g} / \mathrm{l}$, pancreatic digest of gelatin $7 \mathrm{~g} / \mathrm{l}$, bile salts $1.5 \mathrm{~g} / \mathrm{l}$, sodium chloride $5 \mathrm{~g} / \mathrm{l}$, glucose monohydrate $10 \mathrm{~g} / \mathrm{l}$, neutral red $0.03 \mathrm{~g} / \mathrm{l}$, crystal violet $0.002 \mathrm{~g} / \mathrm{l}, \mathrm{pH} \quad 7.4 \pm 0.2$.

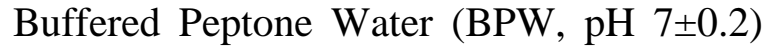
was used for non selective enrichment of sample. In each microbiological experiment, one day old media plates were used. Each experiment was performed twice and in duplicates. $0.8 \%$ agarose gel in TAE buffer was used for electrophoretic separation of DNA samples. Growth temperature for all cultures was kept at $36^{\circ} \mathrm{C}$.

\section{Pre enrichment method}

Pre enrichment of samples was done in Buffered Peptone Water (BPW) as per revised FDA protocol. For this $1 \mathrm{~g}$ of each sample in $10 \mathrm{ml}$ of sterile BPW was incubated at $36{ }^{\circ} \mathrm{C}$ temperature for $\sim 24 \mathrm{~h}$ in shaking (BPW, pH 7士0.2). $1 \mathrm{ml}$ of this preenriched sample was centrifuged at 6000 rpm for 5 minute and resultant pellet was resuspended in $300 \mu \mathrm{l}$ of same buffered peptone water.

\section{Primary Screening}

Cell suspension in buffered peptone water (obtained in previous step) was spread onto violet red bile glucose (VRBG) (HiMedia) agar plates. Growth was observed for Enterobacteriaceae specific colonies after incubation at $36^{\circ} \mathrm{C}$ for $\sim 24 \mathrm{~h}$. Obtained colonies were further streaked on tryptone soya agar (TSA) (HiMedia) following incubation at $36^{\circ} \mathrm{C}$ for next $\sim 24 \mathrm{~h}$ (Steigerwalt et al., 1976). Colonies appearing on TSA plates were tested for presence of Cronobacter contamination following Cronobacter specific PCR.

\section{DNA isolation}

DNA isolation from Enterobacteriaceae colonies was performed following standard protocol given by Rashidat et al., 2013. Briefly, colonies picked from tryptone soya agar plate were resuspended in $50 \mu \mathrm{l}$ of autoclaved water. Samples were heated at $80^{\circ} \mathrm{C}$ temperature for 10 min to release DNA in supernatant, followed by snap chilling on ice for 10-15 min. Samples were centrifuged at $10,000 \mathrm{rpm}$ for $5 \mathrm{~min}$. Cell pellets were discarded and supernatant containing DNA were transferred to fresh tube. Quality of isolated DNA checked by running $0.8 \%$ agarose gel following staining with ethidium bromide.

\section{Primer used in PCR Reaction}

As discussed above, two set of primers were considered for this study. One primer set was based on $r p o B$ gene encoding $\beta$ subunit of bacterial RNA polymerase. Various Cronobacter spp. shares significant sequence similarity in their respective rpoB sequence. rpoB based primer pairs from each strain can amplify rpoB sequence from their respective strains from genus Cronobacter (C. sakazakii; C. turicensis; $C$. 
malonaticus; C. muytjensii and $C$. dublinensis). However, two strains i.e. $C$. sakazakii and $C$. malonaticus can be amplified using single primer pair with no cross-reaction with non-E. sakazakii strains. Sequence of Cmalf primer is (5'-AAC CAG TTC CGC GTT GGC CTG G-3') while Cmalr is (5'-CCT GAA CAA CAC GCT CGG A-3') as described by (Mollet et al., 1997; Stoop et al., 2009). According to them, size of targeted amplicon should be 251 bp for both $C$. sakazakii and $C$. Malonaticus.

Another primer pair was based on internal transcribed spacer (ITS) sequence between between tRNA-glu and 23S rRNA genes. Degenerate primer pair synthesized from ITS region is ESFor (5'ATCTCA AAAMTGACTGTAAAGTCACGTT3') and ESRev is (5'CCGAARAAGTMTTCG KGCTGCGA3') as described by Sylviane Derzelle and Françoise Dilasser (2006). ITS was found to be conserved throughout Eubacteriae, with little difference between genus and species. This can facilitate species differentiation within Cronobacter genus with a mismatch-PCR-based approach. Expected size of targeted amplification with given primer pair is $\sim 158$ bp in all strains of E. sakazakii and no cross-reaction with nonE. sakazakii strains.

\section{Detection by PCR}

Polymerase chain reaction was carried out with PCR, BioRad system. Targeted amplification was performed in $20 \mu \mathrm{PCR}$ reaction containing $1 \mathrm{X}$ Thermopol buffer (20 mM Tris- $\mathrm{HCl} \mathrm{pH}$ 9.2, $10 \mathrm{mM} \mathrm{KCl}$, $10 \mathrm{mM}$ ammonium sulfate, $0.1 \%$ Triton $\mathrm{X}$ 100), $0.2 \mathrm{mM}$ dNTPs, $0.2 \mu \mathrm{M}$ each of the primers and $0.5 \mathrm{U}$ of Taq DNA polymerase. Primer used in this study were Cmalf (5'AAC CAG TTC CGC GTT GGC CTG G3') and Cmalr (5'-CCT GAA CAA CAC 88
GCT CGG A-3') and ESFor (5'ATCTCAAAAMTGACTGTAAAGTCA CGTT3') and ESRev (5'CCGAARAA GTMTTCGKGCTGCGA3') (Sylviane Derzelle and Françoise Dilasser (2006, Stoop et al., 2009). PCR conditions include initial denaturation at $95^{\circ} \mathrm{C}$ for $5 \mathrm{~min}$ and repeated amplification for next 25 cycles. Each cycle further comprised of small denaturation at $95^{\circ} \mathrm{C}$ for $40 \mathrm{sec}$, primer annealing between $47^{\circ} \mathrm{C}-49^{\circ} \mathrm{C}$ (depending on melting temperature of the primers), extension at $72^{\circ} \mathrm{C}$ for 2 hours. Cycles were followed by final extension at $72^{\circ} \mathrm{C}$ temperature for further $10 \mathrm{~min}$. Amplified product was analysed by running $0.8 \%$ agarose gel in $1 \mathrm{X}$ TAE buffer and visualized under UV trans-illuminator (after staining with EtBr solution).

\section{Result and Discussion}

\section{Microbiological detection}

Total of six food samples as mentioned in materials and methods were used in this study. Three health drink samples (A, B and D) while three biscuit samples (C, E and F) were used. Initial screening on violet red blue glucose agar (VRBGA) plates resulted in $~ 500$ Enterobacteriaceae specific red coloured colonies in health drink sample A. Similar colonies were also observed in $\mathrm{E}$ and F biscuit samples. Sample B, D and C didn't show such colonies on VRBGA plate. These red coloured colonies were specific for Enterobacteriaceae contamination (Figure I). Obtained cultures were further streaked on Tryptone Soya Aga (TSA) plates for pure culture.

Secondary Screening of colonies on Tryptone Soya Aga (TSA)

Obtained Enterobacteriaceae specific red colored colonies from VRBGA plates were 
further streaked on Tryptone Soya Aga (TSA) agar plates for further confirmation. For this, five red colored colonies (numbering 1,2,3,4,5) from each VRBGA plates (Health drink A; A1,A2,A3,A4,A5 Biscuit E; E1, E2, E3, E4, E5 and Biscuit F; F1, F2, F3, F4, F5) were streaked on TSA plates. Pale yellow colored colonies appearing on TSA plates further confirmed Enterobacteriaceae contamination these sample (Figure II).

\section{Polymerase chain reaction}

DNA was isolated from five colonies i.e. A1, A2, A3, A4, A5 from Health drink A sample as described in materials and methods. Isolated DNA was used as template in PCR Separate PCR reactions were set up with both rpoB and ITS specific primer pairs. rpoB based PCR should results in 251 bp product while ITS based PCR reaction will give 158 bp amplified product in Cronobacter positive samples (Stoop et al., 2009, Sylviane Derzelle and Françoise Dilasser, 2006). Reactions were performed in duplicates with both pairs of primers. Total of seven Cronobacter spp. characterized, this primer pair (CmalF and CmalR) is capable of amplifying $251 \mathrm{bp}$ rpoB gene region from either of $C$. sakazakii and $C$. malonaticus if present. PCR reaction performed with five colonies from sample A. Samples were analyszed on $0.8 \%$ agarsoe gel stained with EtBr. Cronobacter specific amplification (251bp) was observed in three (A3, A4 and A5) DNA samples. No such amplification in A1 and A2 colonies was observed (Figure III). Althogh all five colonies were microbiologically tested on specific media, negative PCR for A1 and A2 indicate presence of other Enterobacteriaceae spp. whose amplification is beyond these primer pairs. Similar PCR reaction was also carried out with five colonies each from sample $\mathrm{E}$ and
F. Only two colonies from sample $\mathrm{E}$ and $\mathrm{F}$ i.e. E4, E5 (Figure IV), F4, F5 (data not shown) respectively resulted in rpoB based amplification. This could be the because of same reason i.e. presence of other Enterobacteriaceae spp. whose amplification is beyond this primer pairs. Separate PCR with ITS base primer pair was also carried out with similar template DNA. However, none of the template from any of the sample resulted in amplification even when gradient PCR was carried out (Figure III). Therefore according to these findings, microbiological detection followed by rho based conventional PCR can be exploited as the simple but effective Cronobacter detection strategy.

Cronobacter, a multi-species, complex, gram negative, non-sporulating rod shaped bacteria. It has been found responsible for outbreaks causing meningitis and enteritis, especially in infants. Powdered infant formula (PIF) is the most common vehicle of infection resulting in number of neonatal infections. Although Cronobacter do not sustain pasteurization process but heat sensitive nutrients and un-pasteurized raw material can re-contaminate the final powdered infant formula. Other foods found contaminated with this bacterium are skimmed milk powder, herbal teas, starches, wastewater as well as other food supplements. However natural habitat is not well clearly understood. Infants especially less than two months of age, elderly people or infants with compromised immune system are most vulnerable. Associated illness includes neonatal meningitis, necrotising enterocolitis (NEC), bacteraemia, necrotising meningoencephalitis, neurological disorders or even $20 \%$ to $50 \%$ high mortality rate. Various microbiological immuological and molecular methods are already employed in Cronobacter detection. 
Fig.1 Screening food samples on violet red bile glucose (VRBG) agar media plates- Samples suspended in buffered peptone water was either spread or streaked onto violet red bile glucose (VRBG) (HiMedia) agar plates and plates were incubated at $37^{\circ} \mathrm{C}$ for $\sim 24 \mathrm{~h}$. Red colour colonies indicative of Enterobacteriaceae contaiminations appeared on sample (A), (E) and (F) while samples (B), (C) and (D) didn't show any such growth. Sample A, B, C (Health drinks) and D, E, F (High calories Protein Biscuits)

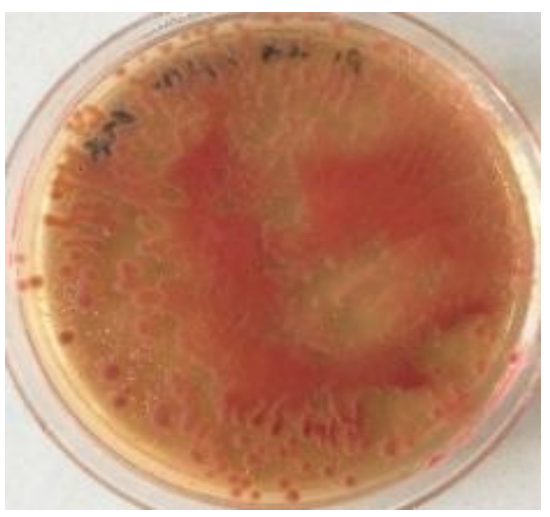

(Sample A)

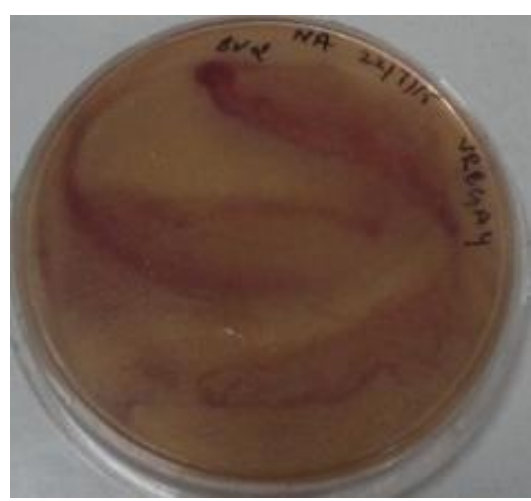

(Sample B)

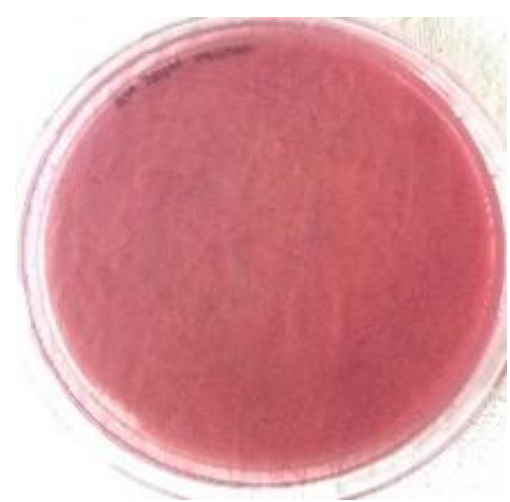

(Sample C)

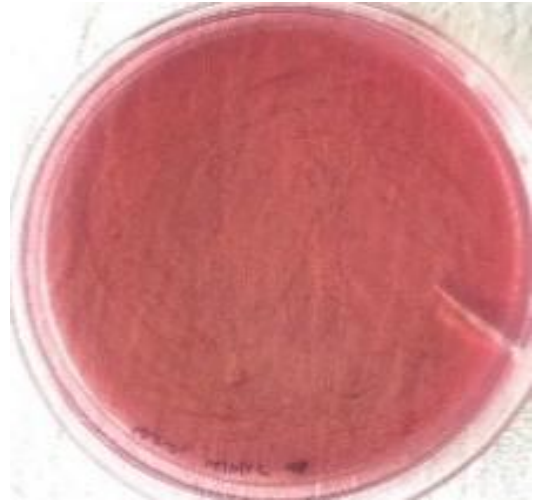

(Sample D)

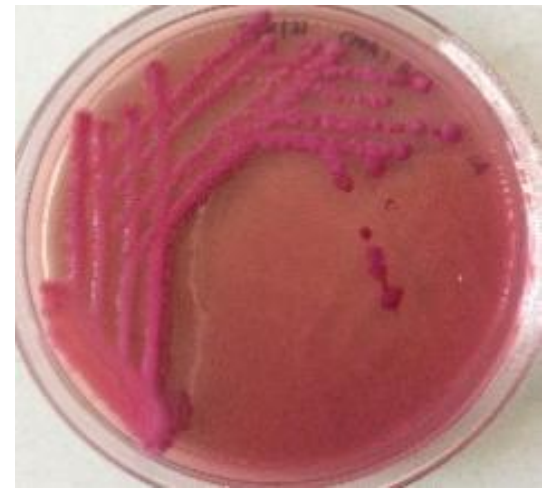

(Sample E)

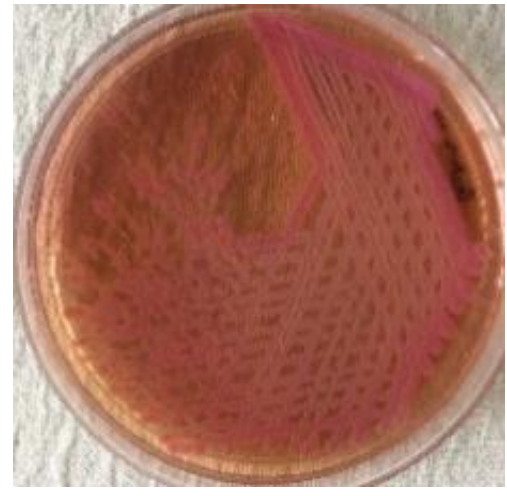

(Sample F) 
Fig.2 Streaking of Enterobacteriaceae colonies on nutrient media i.e. tryptone soya agar (TSA) plates- Red colour colonies appearing in sample A (on violet red bile glucose agar plates) were carefully streaked on nutrient media i.e. tryptone soya agar (TSA) and same were incubated at $37^{\circ} \mathrm{C}$ temperature for $24 \mathrm{~h}$ for confirmation. Same procedure was also performed with colonies appearing in sample $\mathrm{E}$ and $\mathrm{F}$.

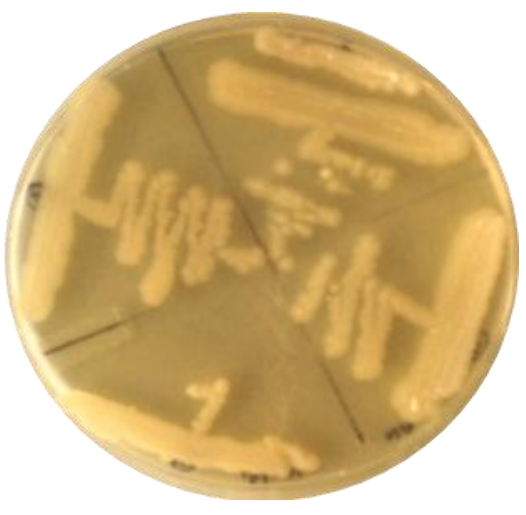

(Sample A)

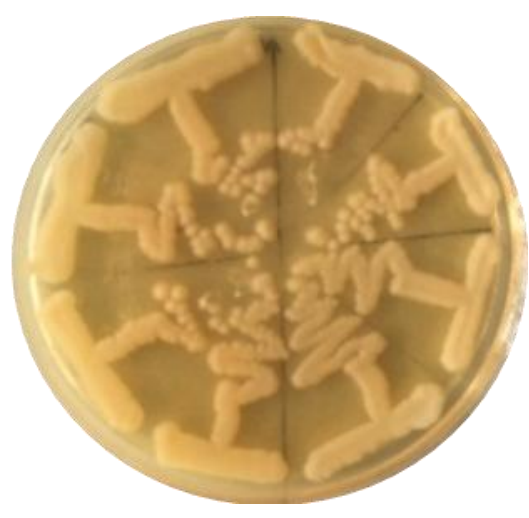

(Sample E)

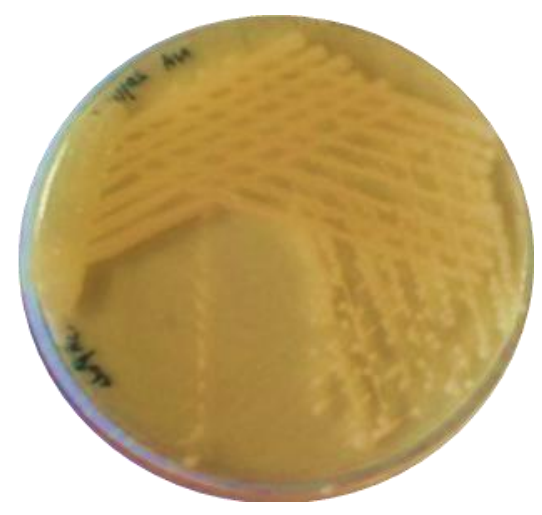

(Sample F)

Fig.3 Detection of $C$. sakazakii in five colonies from sample A by PCR with two sets of primers separately. The PCR products were analyzed by electrophoresis in $0.8 \%$ agarose gel. (A) A 251bp DNA fragment was amplified from rpoB region with rpoBF and rpoBR primers specific for $C$. sakazakii in three (A3, A4 and A5) out of five selected colonies. (B) No PCR amplification was observed in any of above five colonies with ITS specific primers. Lane M-1kb Marker, Lane 2- A1, Lane 3- A2, Lane 4- A3, Lane 5- A4, Lane 6- A5.

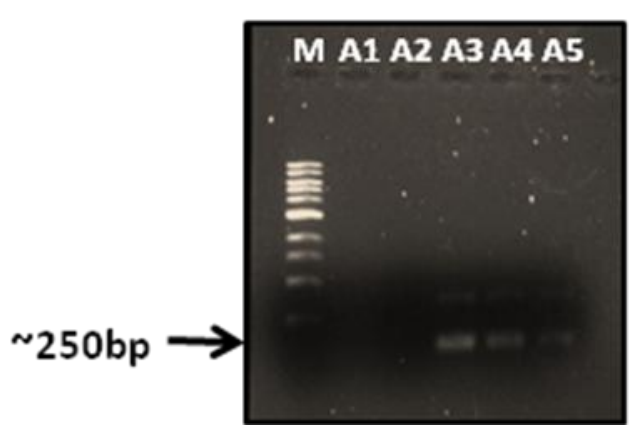

(A)

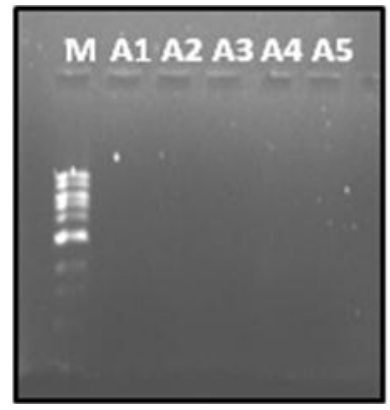

(B) 
Fig.4 Detection of $C$. sakazakii in five colonies from sample E by PCR with two sets of primers separately. The PCR products were analyzed by electrophoresis in $0.8 \%$ agarose gel. A $\sim 251 \mathrm{bp}$ DNA fragment was amplified from rpoB region with rpoBF and rpoBR primers specific for $C$. sakazakii in three (E3, E4 and E5) out of five picked colonies. Lane M-1kb Marker, Lane 2- E1, Lane 3- E2, Lane 4- E3, Lane 5- E4, Lane 6- E5.

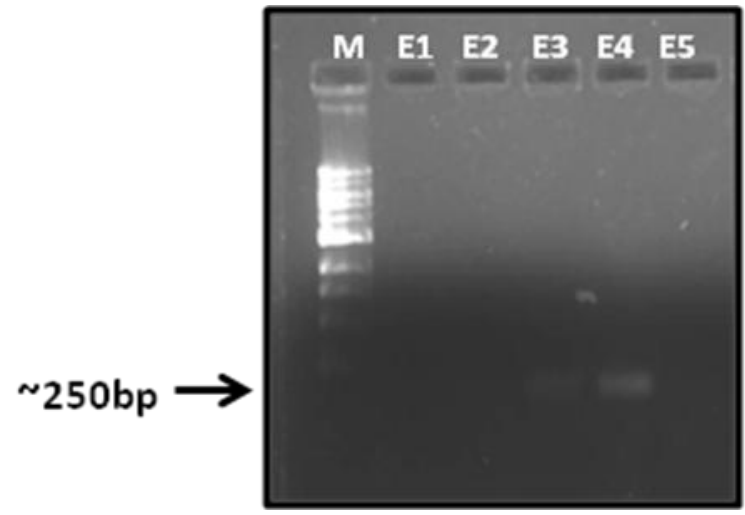

Table.1 Samples used and summary of results obtained from this study

\begin{tabular}{|c|c|c|c|c|c|}
\hline \multirow{2}{*}{$\begin{array}{l}\text { Sr. } \\
\text { No. }\end{array}$} & \multirow{2}{*}{$\begin{array}{l}\text { Sample code/ } \\
\text { name }\end{array}$} & \multirow{2}{*}{$\begin{array}{l}\text { VRBGA } \\
\text { plates }\end{array}$} & \multirow[t]{2}{*}{ TSA Plates } & \multicolumn{2}{|c|}{ Specific PCR amplification } \\
\hline & & & & $\begin{array}{l}\text { With rpoB } \\
\text { based primer }\end{array}$ & $\begin{array}{l}\text { With ITS based } \\
\text { primer }\end{array}$ \\
\hline 1 & A/ Health drink & $\begin{array}{l}\text { Red colour } \\
\text { colonies } \\
\text { appeared }\end{array}$ & $\begin{array}{l}\text { Pale yellow } \\
\text { colour colonies } \\
\text { appeared }\end{array}$ & $+\mathrm{VE}$ & $-\mathrm{VE}$ \\
\hline 2 & B/ Health drink & $\begin{array}{l}\text { No } \\
\text { Colonies }\end{array}$ & No Colonies & $-\mathrm{VE}$ & $-\mathrm{VE}$ \\
\hline 3 & $\begin{array}{l}\text { D/High calories } \\
\text { Protein Biscuits }\end{array}$ & $\begin{array}{l}\text { No } \\
\text { Colonies }\end{array}$ & No Colonies & $-\mathrm{VE}$ & $-\mathrm{VE}$ \\
\hline 4 & C/ Health drink & $\begin{array}{l}\text { No } \\
\text { Colonies }\end{array}$ & No Colonies & $-\mathrm{VE}$ & $-\mathrm{VE}$ \\
\hline 5 & $\begin{array}{l}\text { E/High calories } \\
\text { Protein Biscuits }\end{array}$ & $\begin{array}{l}\text { Red colour } \\
\text { colonies } \\
\text { appeared }\end{array}$ & $\begin{array}{l}\text { Pale yellow } \\
\text { colour colonies } \\
\text { appeared }\end{array}$ & $+\mathrm{VE}$ & $-\mathrm{VE}$ \\
\hline 6 & $\begin{array}{l}\text { F/High calories } \\
\text { Protein Biscuits }\end{array}$ & $\begin{array}{l}\text { Red colour } \\
\text { colonies } \\
\text { appeared }\end{array}$ & $\begin{array}{l}\text { Pale yellow } \\
\text { colour colonies } \\
\text { appeared }\end{array}$ & $+\mathrm{VE}$ & $-\mathrm{VE}$ \\
\hline
\end{tabular}

All the employed methods differ in their specificity and sensitivity.

This study re-evaluated two separate methods based on rpoB and ITS sequence (Table1. Summary of result). Although both studies reported fast and reliable Cronobacter detection, we found rpoB based PCR approach as quite reliable for Cronobacter detection. Mostly infant powder formula milk and infant foods has been screened for Cronobcater detection. This small study tested health drinks and high calories biscuit especially consumed by children. Finding such food samples below acceptable international standards is still a 
matter of concern. Therefore food processing, preparation, handling and storage steps should be scanned by the authority.

\section{Acknowledgments}

I would like to thank UIET, PU for providing facilities to carry out this research work.

\section{References}

Almeida, C., Azevedo, N. F., Iversen, C., Fanning, S., Keevil, C. W. and Vieira, M. J. 2009. Development and application of a novel peptide nucleic acid probe for the specific detection of Cronobacter genomo species (Enterobacter sakazakii) in powdered infant formula. Appl. Environ. Microbiol., 75: 2925-2930.

Anonymous. 2006a. 2006. Milk and Milk Products - Detection of Enterobacter sakazakii. Technical Specification ISO/TS 22964. ISO/TS 22964:2006(E) and IDF/RM 210 (E), 1st edn. Geneva: International Organization for Standardization.

Anonymous. 2006b. Enterobacter sakazakii and Salmonella in powdered infant formula. Available at: http//www.fao.org/ag/agn/agns/jemra_r iskassess- ment_enterobacter_en.asp. Second Risk Assessment Work- shop. Joint FAO/WHO Workshop: Rome, Italy.

Arseni, A., Malamou-Ladas, E., Koutsia, C., Xanthou, M. and Trikka, E. 1987. Outbreak of colonization of neonates with Enterobacter sakazakii. J. Hosp. Infect., 9, 143-150.

Bar-Oz, B., Preminger, A., Peleg, O., Block, C. and Arad, I. 2001. Enterobacter sakazakii infection in the newborn. Acta Paediatr. 90, 356-358.
Baumgartner, A., Grand, M., Liniger, M. and Iversen, C. 2009. Detection and frequency of Cronobacter spp. (Enterobacter sakazakii) in different categories of ready-to-eat foods other than infant formula. Int. J. Food Microbiol., 136, 189-192.

Bej, A.K. 2003. Molecular based methods for the detection of microbial pathogens in the environment. $J$. Microbiol. Methods, 53, 139-40.

Besse, N. G., Leclercq, A., Maladen, V., Tyburski, C. and Lombard B. 2006. Evaluation of the International Organization for StandardizationInternational Dairy Federation draft standard method for detection of Enterobacter sakazakii in powdered infant food formulas. J. AOAC Int., 89, 1309-1316.

Bowen, A. and Braden, C. 2006. Invasive Enterobacter sakazakii Disease in Infants. Emerg. Infect. Dis., 12, 1185-1189.

Chap, J., Jackson, P., Siqueira, R., Gaspar, N., Quintas, C., Park, J., Osaili, T., Shaker, R. 2009. International survey of Enterobacter sakazakii and other Cronobacter spp. 136: 185-188.

Derzelle, S. and Dilasser, F. 2006. A robotic DNA purification protocol and real-time PCR for the detection of Enterobacter sakazakii in powdered infant formulae. $B M C$ Microbiol., 6, 100.

Derzelle, S., Dilasser, F., Maladen, V., Soudrie, N., Leclercq, A., Lombard, B. and Lafarge, V. 2007. Comparison of three chromogenic media and evaluation of two molecular-based identification systems for the detection of Enterobacter sakazakii from environmental samples from infant formulae factories. $J$ Food Prot., 70, 1678-1684. 
Farmer, J. J. III, Asbury, M. A., Hickman, F. W., Brenner, D. J. 1980. Enterobacter sakazakii: a new species of Enterobacteriaceae isolated from clinical species. Int. J. Syst and Evol. Bacter., 30, 569-584.

Friedemann, M. 2009. Epidemiology of invasive neonatal Cronobacter (Enterobacter sakazakii) infections. Eur. J. Clin. Microbiol. Infect. Dis., 28, 1297-1304.

Gurtler, J. B., Kornacki, J. L. and Beuchat, L. R. 2005. Enterobacter sakazakii: a coliform of increased concern to infant health. Int. J. Food Microbiol., 104, $1-34$.

Hassan, A. A., Akineden, O., Kress, C., Estuningsih, S., Schneider, E. and Usleber,E. 2007. Characterizati on of the gene encoding the $16 \mathrm{~S}$ rRNA of Enterobacter sakazakii and development of a species-specific PCR method. Int. J. Food Microbiol., 116, 214-220.

Healy, B., Cooney, S., O'Brien, S., Iversen, C., Whyte, P., Nally, J., Callanan, J. J., Fanning, S. 2010. Cronobacter (Enterobacter sakazakii): an opportunistic food borne pathogen. Food borne Pathog Dis., 7, 339-350.

Iversen, C. and Forsythe, S.J. 2004. Isolation of Enterobacter sakazakii and other Enterobacteriaceae from powdered infant formula milk and related products. Food Microbiol., 21: 771-776.

Iversen, C., Druggan, P., Forsythe, S. 2004. A selective differential medium for Enterobacter sakazakii, a preliminary study. Int. J. Food Microbiol., 96, 133-139.

Iversen, C., Druggan, P., Forsythe, S. 2004. A selective differential medium for Enterobacter sakazakii, a preliminary study. Int. J. Food Microbiol., 96, 133-139.
Iversen, C., Lehner, A., Mullane, N., Bidlas, E., Cleenwerck, I., Marugg, J., Fanning, S., Stephan, R., Joosten, H. 2007a. The taxonomy of Enterobacter sakazakii: proposal of a new genus Cronobacter gen. nov. and descriptions of Cronobacter sakazakii comb. nov. Cronobacter sakazakii subsp. sakazakii, comb. nov., Cronobacter sakazakii subsp. malonaticus subsp. nov., Cronobacter turicensis sp. nov., Cronobacter muytjensii sp. nov., Cronobacter dublinensis sp. nov. and Cronobacter genomo species 1. BMC Evol. Biol., 7:64.

Iversen, C., Mullane, N., Mc Cardell, B., Tall, B. D., Lehner, A., Fanning, S., Stephan, R., Joosten, H., 2008. Cronobacter gen. nov., a new genus to accommodate the biogroups of Enterobacter sakazakii, and proposal of Cronobacter sakazakii gen. nov. comb. nov., C. malonaticus sp. nov., $C$. turicensis sp. nov., $C$. muytjensii sp. nov.,C. dublinensis sp. nov., Cronobacter genomospecies 1, and of three subspecies, $C$. dublinensis sp. nov. subsp. dublinensis subsp. nov., $C$. dublinensis sp. nov. subsp. lausannensis subsp. nov., and $C$. dublinensis sp. nov. subsp. lactaridi subsp. nov, Int. J. Systematic and Evol. Microbiol., 58: 1442-1447.

Jaradat, Z. W., Ababneh, Q. O., Saadoun, I. M., Samara, N. A. and Rashdan, A. M. 2009. Isolation of Cronobacter spp. (formerly Enterobacter sakazakii) from infant food, herbs and environmental samples and the subsequent identification and confirmation of the isolates using biochemical, chromogenic assays, PCR and 16S rRNA sequencing. Microbiol., 9, 225. 
Jarvis, K.G., Grim, C.J., Franco, A. A., Gopinath, G., Sathyamoorthy, V. and $\mathrm{Hu}, \quad$ L. 2011. Molecular characterizationof Cronobacter lipopo lysaccharide O-antigen gene clusters and development of serotype-specific PCR assays. Appl. Environ. Microbiol. 77, 4017-4026.

Mollet, C., Drancourt, M. and Raoult, D., 1997. $r р о B$ sequence analysis as a novel basis forbacterial identification. Mol. Microbiol., 26, 1005-1011.

Mullane, N. R., Drudy, D., Whyte, P., O'Mahony, M., Scannell, A. G. M., Wall, P. G. 2006. Enterobacter sakazakii: biological properties and significance in dried infant milk formula (IMF) powder. Int. J. Dairy Technol., 59, 102-11.

Mullane, N. R., Murray, J., Drudy, D., Prentice, N., Whyte, P., Wall, P.G., Parton, A. and Fanning, S. 2006. Detection of Enterobacter sakazakii in dried infant milk formula by cationic magnetic bead capture. Appl. Environ. Microbiol., 72, 6325-6330.

Mullane, N.R., Healy, B., Meade, J., Whyte, P., Wall, P. G. and Fanning, S. 2008c Dissemination of Cronobacter spp. (Enterobacter sakazakii) in a powdered milk protein manufacturing facility. Appl. Environ. Microbiol., 74, 5913-5917.

Mullane, N.R., Iversen, C., Healy, B., Walsh, C., Whyte, P., Wall, P.G., Quinn, T. and Fanning, S. 2007a. Enterobacter sakazakii an emerging bacterial pathogen with implications for infant health. Minerva Pediatr., 59, 137-148.

Mullane, N.R., O'Gaora, P., Nally, J. E., Iversen, C., Whyte, P., Wall, P. G. and Fanning, S. 2008a. Molecular analysis of the Enterobacter sakazakii Oantigen gene locus. Appl. Environ. Microbiol., 12, 3783-3794.
Mullane, N.R., Ryan, M., Iversen, C., Murphy, M., O’Gaora, P., Quinn, T., Whyte, P., Wall, P. G. 2008b. Development of multiple-locus variablenumber tandemrepeat analysis for the molecular subtyping of Enterobacter sakazakii. Appl. Environ. Microbiol., 74, 1223-1231.

Mullane, N.R., Whyte, P., Wall, P. G., Quinn, T. and Fanning, S. 2007b. Application of pulsed-field gel electrophoresis to characterise and trace the prevalence of Enterobacter sakazakii in an infant formula processing facility. Int. J. Food Microbiol., 116, 73-81.

Muytjens, H. L., Van der Ros-van de Repe, J. And Van Druten, H. M. 1984. Enzymatic profiles of Enterobacter sakazakii and related species with special reference to the $\alpha$-glucosidase reaction and reproducibility of the test system. J. Clin. Microbiol. 20, 684686.

Muytjens, H.L., Roelfos, W. H. And Jaspar, G.H.J. 1988. Quality of powdered substitutes for breast milk with regard to members of family Enterobacteriaceae. J. Clin. Microbiol. 26: 743-746.

Nair, M. K.M. and Venkitanarayanan, K.S. 2006. Cloning and Sequencing of the ompA Gene of Enterobacter sakazakii and development of an ompA-targeted PCR for rapid detection of Enterobacter sakazakii in infant formula. Appl. Environ. Microbiol., 72: 2539-2546.

Oh, S.W. and Kang, D. H. 2004. Fluorogenic selective and differential medium for isolation of Enterobacter sakazakii. Appl. Environ. Microbiol. 70, 5692-5694.

Rashidata, E.A., Olugboa, A. O., Ifeanyib, S. S., Adetounb, F. W., Adedayob, O., and Moses, B. 2013. Isolation and 
PCR Detection of Cronobacter sakazakii from Powdered Infant Formulae retailed in Nigeria. American J. Food and Nutri., 3: 182187.

Restaino, L., Frampton, E. W., Lionberg, W. C., Becker, R. J. 2006. A chromogenic plating medium for the isolation and identification of Enterobacter sakazakii from foods, food ingredients and environmental sources. J. Food Protect., 69, 315-322.

Seo, K.H. and Brackett, R.E. 2005. Rapid, specific detection of Enterobacter sakazakii in infant formula using a real-time PCR assay. J. Food Prot., 68, 59-63.

Steigerwalt, A.G., Fanning, G.R., FifeAsbury, M. A., Brenner, D. J. 1976.
DNA relatedness among species of Enterobacter and Serratia. Can. $\quad J$. Microbiol., 22, 121-137.

Stoop, B., Lehner, A., Iversen, C., Fanning, S., Stephan, R. 2009. Development and evaluation of rpoB based PCR systems to differentiate the six proposed species within the genus Cronobacter. Int. J. Food Microbiol., 136, 165-168.

Wang, M., Cao, B., Gao, Q., Sun, Y., Liu, P., Feng, L., Wang, L. 2009. Detection of Enterobacter sakazakii and other pathogens associated with infant formula powder by use of a DNA Microarray. J. Clin. Microbiol., 10, 3178-84.

\section{How to cite this article:}

Mehal Passi, Nakul Aggarwal and Anu Priya Minhas. 2016. Detecting Cronobacter Contamination in Protein Mixture and Biscuit Sample by Conventional PCR Method-A Preliminary Study. Int.J.Curr.Microbiol.App.Sci. 5(11): 74-85. doi: http://dx.doi.org/10.20546/ijcmas.2016.511.008 